\title{
VADE-MECUM DROGAMI CNOTY O POETYCKIEJ ARETOLOGII CYPRIANA NORWIDA
}

Z pojęciem „cnoty” stykamy się na kartach Vade-mecum niejednokrotnie. Dla czytelnika pism Norwida fakt ten nie może być źródłem zaskoczenia, gdyż „cnota" $\mathrm{i}$ „cnoty” to terminy etyczne pojawiające się w języku pisarza nierzadko, oczywiście wraz z bogatymi kontekstami intelektualnymi, kulturowymi, literackimi i to w obrębie całości dzieła - znajdziemy je w poezji lirycznej i epickiej, prozie artystycznej i publicystycznej, dramaturgii, prywatnej korespondencji - co w pełni potwierdzają badania leksykograficzne autorów internetowego Stownika języka Cypriana Norwida ${ }^{1}$. Co więcej, terminologia tego typu obecna jest we wszystkich fazach twórczości Norwida, poczynając od pierwszych utworów poetyckich z okresu warszawskiej młodości, takich jak Dumanie [II], Burza, Pożegnanie, aż po kres twórczego życia, znaczony $\mathrm{m}$. in. Milczeniem. Tak konsekwentne powroty pisarza do języka i problematyki cnoty muszą prowokować do rozważenia serii pytań: o źródła, artystyczny i intelektualny sens oraz cel tych autorskich wyborów. Na początek warto odnotować, że w ponad czterdziestoletnim przedziale czasowym swej aktywności pisarskiej Norwid zasadniczo nie podważa utrwalonego, popartego wielowiekową tradycją, rozumienia słowa oraz towarzyszącego mu nacechowania aksjologicznego ${ }^{2}-$, ,nota” jest zawsze synonimem wysokich

${ }^{1}$ Wyodrębnione w słowniku zakresy znaczeniowe terminu „,nota” to: 1) zespół dodatnich cech moralnych (i obyczajowych); 2) moralnie dodatnia cecha człowieka; 3) dziewiczość, czystość.

${ }^{2}$ Samuel Bogumił Linde podaje jako podstawowe znaczenie terminu: „ogół, zbiór własności, skłonności, uczynków rozumnego stworzenia z powinnością jego zgodnych, a za tym zasługujących na zaletę, ciąg usiłowania, by dogodzić swoim obowiązkom”, a dalej licznymi przykładami 
i akceptowanych przez poetę wartości, nie podlegających racjonalnemu kwestionowaniu ani poetyckiemu ironizowaniu. Zarazem operuje tym pojęciem ciekawie różnicując, w obrębie znaczenia podstawowego, akcenty semantyczne ${ }^{3}$. Jak w sumie rozległe, bogate i wewnętrznie zniuansowane jest pole znaczeniowe "cnoty” w języku Norwida niech unaocznią wybrane przykłady, zaczerpnięte z różnorakich pism poety.

Znajdziemy w nich szereg fraz, w których cnota stanowi oznakę wartości człowieka i prowadzonego przezeń życia; okazuje się jego celem, drogowskazem, wzorem, ideą przewodnią. Tak rozumianej cnocie Norwid, zwłaszcza we wczesnej fazie twórczości, składa poetycki hołd, formułując przy tym, w tonie jednoznacznie deklaratywnym, ważkie pouczenia, niemal dewizy życiowe:

Śmiało więc zdążaj ku przeczystej cnocie,

Jeśli zaś burza wyrwie ci wawrzyny,

Myśl wskrzeszać będzie naśladowców krocie,

A w posąg własne skamienieją czyny!

$$
\text { (Burza [I], PWsz I, 48) }{ }^{4}
$$

[...] jakby, zbawion ludzkich ułomności, [mowa o „,człeku” - A. Z.]

Mnóstwo szyderstw i wściekłych utyskiwań mnóstwo

Odepchnął znakiem krzyża, jak pogańskie bóstwo,

I tylko siłę cnoty, tylko czystość cnoty

$\mathrm{Na}$ chwilowymi wieki nie ugiętej głowie

Piastuje świątobliwie, niby promyk złoty,

Blady, drżący, jak swarem pożółkłe sitowie.

(Dumanie [II], PWsz I, 41)

Biedni ludzie! niech im cnota

Rozpromieni noc żywota...

(Pożegnanie, PWsz I, 53)

- Nie, Bracie, ja nie mogę patrzeć na suchoty

Tu, tam, trapiące żywot p o b ł a ż a n i e m... c n o t y!...

zastosowania słowa potwierdza jego powszechną i żywą obecność w języku polskim (zob. tenże, Stownik języka polskiego, t. I, Lwów 1854, s. 318-319).

${ }^{3}$ Analogicznie postępuje Mickiewicz (por. Słownik języka Adama Mickiewicza, red. K. Górski, S. Hrabec, t. I, Wrocław 1962, s. 491-493), w którego języku „cnota” jest zasadniczo nazwą postępowania, zgodnego z zasadami moralnymi, ale kojarzona jest też z rozumem, nauką, pięknem, wdziękiem, czystością, kobiecością, postawą etyczną i pogańską, i chrześcijańską.

${ }^{4}$ Prócz edycji DW, PWsz w artykule wykorzystuję także edycję Vade-mecum: C. NorwID, Vade-mecum, oprac. J. Fert, wyd. 2, zmienione, Wrocław 1999 (dalej jako VM, cyfrą arabską oznaczam stronę). 
- Cnota jest zdrową siłą: buduje, nie traci,

Pobłażań też nie czeka i wspaniale płaci,

Królewski mając akcent, i kmiecą rzewliwość,

I moc - a ta jest w sobie oliwna jak tkliwość.

([Na jakie stać mię, bracie - takieć piszę listy], PWsz I, 242)

Norwid traktuje zatem cnotę nie tylko jako przedmiot czci, uwielbienia, ale również jako dziedzinę nauczania, czynnik formowania człowieka na wzór starożytnej paidei, gdzie problem areté był jednym z kluczowych zagadnień etyczno-pedagogicznych ${ }^{5}$. W jego twórczości padają w tym kontekście imiona Homera, Sokratesa i Platona (w związku z formą Platońskiego dialogu, prowadzonego przez ,ludzi zwykłych, ludzi na ulicach Aten spotykanych, a poszukujących nieznanego Boga, prawdy i cnoty śród doczesnych i arcypotocznych bytu warunków"; Milczenie, PWsz VI, 225), a także Plutarcha (myśliciel, jako autor Żywotów sławnych mężów, skojarzony zostaje ze szkolnym nauczaniem cnoty w formie anegdot: „Których by kiedyś z retorycznym szumem / Uczono w szkołach, chcąc nauczyć c n o t y; / A nowy Plutarch - w nowe wlał żywoty..."; W pamiętniku L. A. Improwizacja, PWsz I, 73) oraz Pitagorasa, stoików i cyników jako antycznych mistrzów cnoty ${ }^{6}$. Ciekawym przykładem może być w tym kontekście $Q u$ idam, w którym formację intelektualną i duchową Aleksandra z Epiru Norwid przedstawia następująco: „W śmierć wierzac - jako w szczelnie zwarte wrota, / W miłości napój wiosenny i w wiedzę / Matematyczną - i w dźwięk słowa: cnota. / Blisko znaczący wyrazowi: zdrowie / I wyrazowi siła - rzecz podobna / Do zaklęć, których jasno nikt nie powie, / A która wszakże jest, i jest osobna" (DW III, 229). Znamienne, że autor poematu eksponuje związek cnoty ze zdrowiem (zdrowiem ciała i duchową mocą), pozostając tym samym w kręgu myśli etycznej starożytności, często eksponującej ten właśnie związek. Doktryny Platona i Arystotelesa ściśle kojarzyły zalety duszy z zaletami ciała, antropologię wiązały z medycyną ${ }^{7}$.

${ }^{5}$ Zob. W. JAEGer, Paideia. Formowanie człowieka greckiego, przeł. M. Plezia, H. Bednarek, Warszawa 2001; J. KuREK, Paideia rzymska. Model formowania człowieka w myśli Seneki, Epikteta i Marka Aureliusza, Warszawa 2016.

${ }^{6}$ Szerzej o roli tradycji pitagorejskiej oraz sokratyczno-platońskiej i stoicko-cynickiej w paideutycznym wątku twórczości Norwida pisałam już wcześniej. Zob. $O$ „,rozmowy duchu”, czyli o dialogowej formie „Promethidiona”, w: Poszukiwanie wspólnoty. Estetyka dramatyczności a więź międzyludzka w literaturze polskiego romantyzmu (preliminaria), Kraków 2011, s. 165-196; W stronę Diogenesa. Z problematyki Norwidowskiej koncepcji kultury, „Wiek XIX” 2015, s. 297-316; Pochwała kontemplacji. Norwid wobec Pitagorasa i pitagoreizmu, w: Loci (non)communes. Prace ofiarowane Profesor Marii Korytowskiej, red. O. Płaszczewska, M. Siwiec, Kraków 2017, s. 81-98.

7 Zob. Z. PAŃpuch, Areté, w: Powszechna encyklopedia filozofii, red. nacz. A. Maryniarczyk, Lublin 2004, t. 1, s. 320; Tenże, Aretologia, w: tamże, s. 325-329; Tenże, W poszukiwaniu szczęścia. 
Również paideia chrześcijańska koncentruje się na kwestii cnoty, o czym Norwid doskonale pamięta, powołując się wprost na biblijne wzory osobowe cnót: np. na Dawida z harfą „promienną jak cnoty” (Rzecz o wolności słowa, DW IV, 235), na Matkę Boską jako „współ-pracującą wszystkimi cnotami” (Do Najświętszej Panny Marii. Litania, PWsz I, 193), oczywiście współpracującą w dziele zbawienia, dlatego zyskuje w litanii przydomek „Kończąca wszystko”, lokrotnie wskazując, choć niekiedy pośrednio, na Jezusa Chrystusa - Mesjasza obdarzonego pełnią cnót (Iz 11,2), osobowe wcielenie cnót, ich wzór i nauczyciela.

Cnota jest nierzadko kojarzona przez pisarza z sytuacją duchowych ćwiczeń, prowadzonych w relacji mistrz - uczeń ${ }^{9}$ lub indywidualnie, poprzez duchowe rozważania, moralne i nabożne rozmyślania, a także z sytuacją psychomachii, czyli w myśl znaczenia tego terminu: „walki w ludzkiej duszy”, „walki o ludzką duszę" lub „walki o ocalenie ludzkiej duszy, czyli siebie” - z wadami, występkami, grzechem, złem $^{10}$. W dobrze znanym fragmencie Quidama zmagania te uzysku-

Śladami aretologii Platona i Arystotelesa, Lublin 2015. Podobnie w chrześcijańskiej nauce moralnej grzech przedstawiany bywa jako choroba duszy, zaś cnota jako fundament i oznaka zdrowia, a zatem czynnik umożliwiający prawdziwie chrześcijańskie życie, przeciwstawiane duchowej śmierci.

${ }^{8}$ W ikonografii chrześcijańskiej spotykamy zarówno przedstawienia Dawida w otoczeniu cnót (np. Dawid z Mocą, Mądrością i Proroctwem, Psatterz paryski, IX w.), jak i, bardzo szeroko spopularyzowane, wyobrażenia Matki Boskiej w otoczeniu cnót. Zob. A. KatzenelLenBogen, Allegories of the Virtues and Vices in Medieval Art. From Early Christian Times to the Thirteenth Century, New York 1939.

${ }^{9}$ Referat na temat śladów tradycji filozoficznych ćwiczeń duchowych w twórczości Norwida przedstawiłam na konferencji „, Tyś osoba”. Osoby w kręgu biografii i twórczości Cypriana Norwida, która odbyła się na Uniwersytecie Mikołaja Kopernika w Toruniu 27-28 września 2018 r.

${ }^{10}$ Motyw zmagań o duszę człowieka pojawia się w literaturze wczesnochrześcijańskiej, np. w żywocie św. Antoniego autorstwa św. Atanazego (ok. 357 lub 365), ale do jego spopularyzowania przyczyni się przede wszystkim utwór pt. Psychomachia chrześcijańskiego poety Aureliusza Klemensa Prudencjusza (ur. 348 - zm. ok. 413), przedstawiający moralne zmagania dobra ze złem jako serię walk toczonych między personifikacjami różnych cnót i występków (zob. ks. M. STAROWIEYSKI, „Psychomachia” Prudencjusza, czyli katecheza o cnotach i grzechach, „Ethos” 2010, nr 92, s. 171-182; S. StabrYŁa, Chrześcijański świat poezji Prudencjusza, Kraków 2011, s. 54-91). Na początku XV wieku ten typ przedstawień łączy się z rozwijającym się wówczas motywem „dobrej śmierci"; efekty tej syntezy znajdziemy zwłaszcza w traktatach artis bene moriendi, moralitetach, literaturze ascetycznej (najczęstsza wersja to walka anioła z szatanem lub starcie człowieka z duchami zła, personifikacjami pokus i grzechów). Zob. M. WŁodARSKI, Motyw ,,psychomachii' w literaturze polskiej XV i XVI wieku, „Pamiętnik Literacki” 1983, z. 2, s. 3-22. Przy okazji warto odnotować, że niezwykle ważny dla Norwida temat „dobrego umierania” powiązany jest w tradycji z problematyką cnoty. Jednak wiersze poety podejmujące kwestię śmierci nie zawierają bezpośrednich nawiązań do zagadnień aretologicznych i tym samym nie zostaną uwzględnione w moich roz- 
ją wymiar wręcz kosmiczny, współtworząc etyczno-metafizyczno-religijną ramę zarówno dla sytuacji historycznych przedstawionych w poemacie, jak i dla jego historiozoficznej semantyki:

Pomiędzy świtem a nocy zniknięciem

Płomienne blaski różowe $\mathrm{z}$ mrokami

Walczą, jak cnota z świata-tego księciem -

Mdławe, lecz ufne, choć wciąż je coś mami.

(DW III, 131)

W polu pojęciowo-obrazowym Norwidowskiej cnoty znajdują się: światło, dobro, prawda, piękno, natchnienie Boże, moc (cnota jako „boska siła w ciele człowieczości mdławej”; Odpowiedź krytykom „Listów o emigracji”, PWsz VII, 35), zdrowie, serce, sumienie ${ }^{12}$, obowiązek, niewinność, czystość (Dumanie [II]; PWsz I, 41), dziewiczość, a nawet w ogóle kobiecość (np. Do wieśniaczki), bo w dawnej ikonologii i emblematyce, o czym przypomina Norwid w Emancypacji kobiet, cnota jest niewiastą (PWsz VI, 653) ${ }^{13}$. Co więcej, poeta często różnicuje cnoty, pisze więc o „cnotach-ludzkich” (List do Marii Trębickiej, 28 sierpnia 1857; DW XI, 186), domowych, obywatelskich, arystokratycznych (,,nota wrodzonego dostojeństwa”; List do Władysława Czartoryskiego, Paryż 1881; PWsz X, 164), duchowych: pogańskich i chrześcijańskich, eksponując raz relację ciągłości między nimi, raz ich opozycyjność (w tragedii Słodycz, akcentując opozycyjność cnót pogańskich i chrześcijańskich, Pamfilius mówi: ...Cnota u nas jest zapałem / Iskrą boską... U chrześcijan ciemnych jest to niby / Płyn... eter... płyn przejrzysty jak

ważaniach. Obecność elementów psychomachii w poezji Norwida odnotowywał Józef FerT, wiążąc ten motyw z utworami Przeszłość i Przyszłość oraz Addio! (zob. tenże, Poeta sumienia. Rzecz o twórczości Norwida, Lublin 1993, s. 153).

${ }^{11}$ Przytoczmy również słowa pochodzące z interpretacji Psychomachii Prudencjusza: „Rozgrywające się w duszy człowieka zapasy między dobrem i złem, między cnotami a grzechami, są jednocześnie zmaganiem się chrześcijaństwa z pogaństwem, światła z ciemnością, a zwycięstwo cnót oznacza triumf miłości Bożej nad barbarzyństwem" (zob. S. STABRYŁA, Z badań nad poezja Prudencjusza, w: Stromata historica in honorem Romani Mariae Zawadzki, Kraków 2006, s. 679).

${ }^{12}$ Wyczerpująco na temat Norwidowskiej semantyki sumienia pisał Józef FerT (zob. idem, Poeta sumienia), uznając je za jedno z kluczowych pojęć etycznych w języku pisarza. Związane z prawdą i prawem, zachowujące autonomię wobec sfery subiektywności, w tym uczuć, wymagające samopoznania, sumienie stanowi - jak dowodzi badacz - organ życia moralnego osoby i narodu. Zakresy pojęć ,sumienie” i „,cnota” nie są rozłączne w poezji Norwida, niekiedy zachodzą na siebie, jednak sumienie ma tu ewidentnie chrześcijańskie i raczej nowożytne konotacje, zaś cnota ewokuje etyczne tradycje świata starożytnego, również wczesnochrześcijańskiego.

${ }_{13}$ Szereg przykładów personifikacji cnót zawiera np. popularne kompendium Cesarego Ripy. Zob. C. RIPA, Ikonologia, przeł. I. Kania, Kraków 2004. 
lodowe szyby. / [...] I stąd ta... pewna... stodycz!...; DW V, 283-284) ${ }^{14}$. Odnosząc się do cnót chrześcijańskich, pisarz najczęściej powołuje się na cnoty teologiczne: wiarę, nadzieję i miłość, konsekwentnie kładąc nacisk na ich jedność, współdziałanie, co stanowi od wieków ważny temat i filozofii, i teologii moralnej ${ }^{15}$. W Zarysach z Rzymu pisze wprost:

Ale podobno wszystkie doby chrześcijańskiego społeczeństwa w jednej z trzech cnót węgielnych rozmiłowały się szczególnie, zapominając, iż do każdej przez inne jest droga. I oto była doba WIARY bez miłosierdzia i nadziei -i MIŁOŚCI doba, tak pamiętna z najabsolutniejszego $\mathrm{n}$ i e d o w i a r s t w a, a dziś jesteśmy o NADZIEI, lecz - ile dotąd sądzić można - zbyteczną w i a rą nie grzeszymy, a zaś miło śc i, śmiało powiem, iż brak dość jest widoczny. Nadzieja wszakże bez dwóch drugich współ-cnót, współ-sił, współ-pojęć, z proroczej nagle wysokości na potoczne spada s p o d z i e w a n i e, które nie tylko kroków butnych, ale i samej bezczynności uniewinnić nie może" (PWsz VII, 13) ${ }^{16}$.

${ }^{14}$ Norwid, charakteryzując postawę chrześcijańską, koncentruje tu swą uwagę na pojęciu słodyczy, bo stoi za nim ewangeliczna proweniencja oraz obecność w chrześcijańskiej apologetyce (np. Tertulian), ale należy też pamiętać o równie ważnej dla pisarza idei heroiczności cnót, w obrębie której chrześcijaństwo korzystało z wzorców pogańskiego heroizmu, a zarazem je reinterpretowało. Heroiczności cnót przypisano zatem taki stopień cnót chrześcijańskich, który osiąga osoba praktykujące je bez wyrachowania i dla nadprzyrodzonego celu (z udziałem Ducha Świętego), przekraczając zwykłą miarę doskonałości moralnej. Teologiczny sens pojęcia wypracował św. Tomasz, a jego sens kanoniczny - na użytek procesów beatyfikacyjnych i kanonizacyjnych - papież Benedykt XIV (1841). Zob. H. MiszTaL, Heroiczność cnót, w: Encyklopedia katolicka, red. zbior., t. IV, Lublin 1993, szp. 798-799.

${ }^{15}$ Myślicielem, który zapoczątkował teorię współdziałania cnót był Platon, wskazujący na sprawiedliwość jako cnotę kierowniczą wobec pozostałych cnót (mądrość, męstwo, umiarkowanie) i gwarantującą harmonię między sferą psychiczną a polityczną. Według Arystotelesa to roztropność odgrywa rolę nadrzędną, stanowi dla pozostałych cnót podstawę, jest czynnikiem ich spójności, ale też sama od nich zależy. Z kolei w filozofii stoickiej poszczególne cnoty zostają podporządkowane apathei, będącej głównym celem życia moralnego. W chrześcijańskiej systematyce cnót, podlegającej stosunkowo częstym modyfikacjom, zależnym od przyjmowanej koncepcji osobowości ludzkiej, pierwszeństwo i rolę kierowniczą przypisywano raz męstwu (św. Ambroży), raz miłości (św. Augustyn), kiedy indziej pokorze (św. Grzegorz I Wielki) czy roztropności jako cnocie zarazem moralnej i intelektualnej, ale będącej też, jak wszystkie cnoty, formą wyrazu miłości (św. Tomasz z Akwinu). Oczywiście na tle antropocentrycznie zorientowanej aretologii starożytnych chrześcijańską aretologię wyróżniał właściwy jej teocentryzm - transcendentny Bóg stanowi ostateczny cel cnotliwego życia i źródło jego spełnienia.

${ }^{16}$ Zob. też: O Juliuszu Stowackim (PWsz VI, 409), gdzie mowa o nadziei w powiązaniu z tajemnicą Bożego Narodzenia: „kapłanowie nadziei nie mieli już co robić u Betlejemskiego żłobu. Nadzieja wszelako odsłoniła nam przez to samo opony i pokazała pierwociny całokształtu architektury swojej, objawiła się niejako i stała się j e d n ą z trzech cnót, gdy pierwej była j e d y n ą". Również w liście do Konstancji Górskiej (Paryż, I poł. września 1862) Norwid przedstawia swe 
W zakończeniu powyższego cytatu wybrzmiewa jeszcze jeden istotny aspekt Norwidowskiego mówienia i myślenia o cnocie. Otóż w potocznym życiu XIX stulecia pisarz dostrzega poważne deficyty cnoty. Również w innych miejscach jego pism ujawniają się podobne przeświadczenia: powoływanie się na cnotę staje się w jego czasach frazesem, ,dekoracją” ([Pierwszy list, co mnie doszedt z Europy]; PWsz I, 218 ), gestem bez istotnego znaczenia, pozorem. W efekcie życie traci walor tak pożądanego przez Norwida serio, z którym poeta nieodmiennie kojarzy cnotę, pod znakiem zapytania staje bowiem duchowa głębia, powaga i sens ludzkiego istnienia. W liście do Józefa Zaleskiego (Paryż, ok. 20 czerwca 1856) konstatacja ta wynika z rozważań na temat zagadnienia jedności cnót, sprzężonego z kwestią jakości życia indywidualnego i zbiorowego:

Z wieści od świata świętych i ja wiem nieco, bo Pan na osoby względu nie ma... dlatego tylko i ja wiem - ale cóż?

Kiedy nie ma Nadziei jako cnoty,

Wiary jako siły,

Miłości jako prawdy,

tylko jest spodziewanie się, czyli fortuna - wierzenie formalne i mitowanie, jak się podoba... Przy tym zatracone jest wszelkie szczere serio - jakoby że Naczynie poważne zgubione, a bez tego żadna całość zbiorowa i pojedyncza nawet - nie ostoi się. To, czego nam (Polakom) brak, to nie ziemi polskiej nawet, ale Naczynia poważnego. Ja nie prorokuję żadnych fałszywych zmian - wszystko będzie, co jest, tylko wszystko z wyższego źródła, a co nie wytrzyma tej próby - to w proch pójdzie (DW XI, 76-77).

Na tym tle Vade-mecum można uznać za punkt kulminacyjny Norwidowskiej aretologii. Pojęcie cnoty staje się tu integralnym elementem języka poetyckiego autora, ściśle przynależy do świata jego idei i wyobraźni. Powraca ono w cyklu wielokrotnie - przywoływane jest wprost lub sugerowane przez kontekst historyczny,

rozumienie Nadziei-cnoty, „która jest z Wiarą i Miłością stawiona w rzędzie jednym”, przypominając o jej chrześcijańskim fundamencie: „Ależ powiedziane nam było i nie zakryte, że światłość w c i e m n o ś c i a c h świeci - a ciemności Jej nie ogarnęły!” (PWsz IX, 53-54). Z kolei w liście do Józefa Ignacego Kraszewskiego (Paryż, maj 1866) pisarz podkreśli wagę związku prawdy i nadziei: „ufanie w konsekwencje prawdy zwie się NADZIEJĄ (c notą)” (PWsz IX, 222). Tak silne skoncentrowanie uwagi Norwida na Nadziei jako cnocie kryje w sobie, jak sądzę, ważny akcent polemiczny, którego adresatem są rozmaici romantyczni prorocy, głoszący jego zdaniem powierzchownie rozumianą nadzieję. Jak widać, Norwidowska aretologia sąsiaduje z kwestią stosunku Norwida do romantycznego profetyzmu, rozumianego jako postawa i estetyka poezji zarazem. 
personalny, etyczny. $Z$ bezpośrednim przywołaniem pojęcia mamy do czynienia w utworach: XIII. Larwa, XXXV. Ironia, XXXVIII. Zawody, XXXIX. Centaury, $L X X V$. Ideat i reformy, XCIX. Fortepian Szopena. Ale również w innych wierszach, takich jak np. XXX. Fatum, XLI. Królestwo, LXXIV. Bohater, problematyka ta dochodzi do głosu, acz pośrednio, bez leksykalnych odniesień do cnoty. Co więcej, XLV. ogniwo Vade-mecum nosi tytuł Cnót-oblicze i cnota stanowi w tym przypadku tematyczne centrum utworu, który pomyślany został niewątpliwie jako wiersz kluczowy dla Norwidowskiej wykładni cnoty w obrębie cyklu. Znajdziemy tu splot ważnych dla Norwida ujęć zagadnienia: wywyższenie cnoty jako ideału ludzkiego życia, poetyckie definiowanie areté jako męstwa, obrazowanie triumfu cnoty „wszech-królujacej wielmożnie” (VM, 86), jej sakralizowanie za pośrednictwem wizji posągu wprowadzanego do kościoła (,W Kościół Tryumfu wysoki”; VM, 87), antropomorfizowanie cnoty (w tytule mowa o „cnót-obliczu”), przedstawienie aktu ,widzenia”, czy też sekwencji „widzeń” cnoty w optyce dramatyczno-teatralnej (cnota tragiczna, cnota dramatyczna, ta trzecia - być może komediowa). Wykorzystanie metaforyki teatralnej może prowadzić czytelnika zarówno ku Norwidowskiej koncepcji dramatyczności bytu, tak mocno akcentowanej np. w wierszu L. Bliscy, gdzie przedmiotem poetyckiej analizy staje się „ślad dramatyczny bytu” (VM, 91), przybierający rozmaite formy, jak i w stronę jego koncepcji teatru - jako przestrzeni samopoznania i doskonalenia się osób oraz społeczeństw, jako niezwykle ważnego organu formowania moralności człowieka ${ }^{17}$. Niestety, zdefektowany tekst nie pozwala na precyzyjną i konkluzywną interpretację.

Jednak pomimo braku kompletnej wersji wiersza, tak ważnego dla poruszanej problematyki, można, wziąwszy pod uwagę widoczne w całym dziele Norwida myślenie kategoriami cnoty, zaryzykować tezę, że wątek aretologiczny współtworzy w Vade-mecum ową „misterną nić wewnętrzną”, o której autor wspomina w liście do Merzbacha (z 7 czerwca 1866; PWsz IX, 288), że jest on jednym z czynników spójności cyklu i to na kilku poziomach.

Po pierwsze, na poziomie podmiotu autorskiego i kreacji podmiotu dzieła, którego ważnym aspektem jest Ja moralisty. Pamiętamy, że postulowany przez Norwida „skręt konieczny w poezji polskiej” ma na celu m. in. zażegnanie kryzysu, o który Norwid obwinia również swych „wielkich i słynnych poprzedników” tymi słowami:

${ }^{17} \mathrm{~W}$ tym duchu teatr zostaje przez Norwida zinterpretowany we Wstępie do Pierścienia Wielkiej-Damy. Okazuje się tu instytucją artystyczną i społeczną, przed którą stoją ważkie zadania moralne, otwiera bowiem ,pole do budującego działania wobec chrześcijańskiego społeczeństwa” (DW VI, 110), a mówiąc inaczej: uczestniczy w formowaniu go wedle reguł cnoty. 
Wszelako: szkoła ta, cechująca się rozjaśnianiem i wyrokowaniem o szerokich historycznych sytuacjach lub o praw a ch n a rod u, nie miała zapewne dosyć czasu, aby w utworach jej strona o b o w i ą z k ó w, strona $\mathrm{m}$ o r a $\mathrm{ln}$ a, znaczne zajmowała miejsce... W ogóle literatury naszej m or a li ś c i zbyt szczupłym są zastępem dlatego, że położenie narodu daje więcej folgi głosom o p raw a wołającym niźli zajmującym się o b o w i ą z k a m i $(\mathrm{VM}, 8)^{18}$.

A zatem dla poezji, pogrążonej w upadku, antidotum stanowić może zwrot ku źródłowym moralnym jej powinnościom, co w odniesieniu do twórcy oznacza konieczność wejścia rolę moralisty, dla którego kategoria cnoty musi być ważnym punktem odniesienia. O własnym dziele Norwid napisze, przypomnijmy, iż jest ono ,jakoby idącą już w te strony nowe poezją" (List do Henryka Merzbacha, Paryż, ok. 25 czerwca 1866; PWsz IX, 236) być może także dlatego, że stanowi przykład poetyckiego propagowania cnoty.

Po drugie, wątek aretologiczny uczestniczy w uspójnianiu Vade-mecum również na poziomie narracyjnym cyklu (w obrębie jego epickiej dominanty) ${ }^{19}$. Jeśli przyjąć za Juliuszem Gomulickim i Józefem Fertem, że semantyka tytułowej apostrofy obejmuje między innymi wezwanie, by iść ze mną, iść za mną ${ }^{20}$, czyli wraz z poetą-moralistą, którego twórczość powinna być dla czytelnika wskazówką, zachętą do ,przemyśleń, przeznaczonych do codziennego rozważania i doskonalenia się wewnętrznego" 21 , to zawarta w tytule aluzja do drogi, wędrówki, podróży, ma analogię w szeroko rozpowszechnionym w dyskursie aretologicznym obrazowaniu - cnotę pozyskuje się, kultywuje, rozwija w trudzie kroczenia jej drogami,

18 W listach do Henryka Merzbacha z roku 1866, dotyczących Vade-mecum, Norwid nadaje tej idei nieco odmienną formę: „C zę ść moralna i obowiązkow a jest u poetów naszych na stanowisku wyjątku i maleńkiego odsyłacza, ale nie uzasadnia i nie uźródla poezji: m oralis tó w prawi e ni e ma my" (PWsz IX, 236). Poeta krytycznie wypowiada się na temat swych kolegów po piórze, uznając że jak pensjonarki, ,niepewne swej cnoty i jej zasad”, ,grzeszą przez brak czujności i b r a k o d w a g i c y w i l n e j”. Przeciwstawia im własne stanowisko, respektujące wymogi cnoty: ,Ja odpowiadam sam przed publicznością i jej w i e k i e m" (PWsz IX, 233). Po latach w eseju Emancypacja kobiet pisarz ponownie stwierdzi: „M o r a 1 i s t ó w literatura spółczesna polska wcale nie ma i podobno że mieć nie może, albowiem przeważny jest rozwój d z i e nnikarstw a i powi és c i”, które stawiając sobie za cel ,z a d o w o l e n i e p u b 1 i c z n o ś c i”, nie są w stanie podjąć walki o moralne pryncypia (PWsz VI, 652).

${ }^{19}$ O związkach między formami narracji, zwłaszcza tymi konstytuującymi wspólnotę, a pedagogiką cnoty pisze inspirująco A. MacInTYRe. Zob. tenże, Dziedzictwo cnoty. Studium z teorii moralności, przeł. A. Chmielewski, Warszawa 1996.

${ }^{20}$ Nie jest moją ambicją rozstrzyganie, która $\mathrm{z}$ formuł jest bliższa intencjom poety. Zob. J. W. GoMULICKI, Norwidowe „Idź za mna”, w: C. Norwid, Vade-mecum, tekst opracował oraz wstępem i dodatkiem opatrzył J. W. Gomulicki, wyd. 2, zmienione, Warszawa 1969; J. FERT, komentarz (VM, 3-4).

${ }^{21}$ J. FERT, komentarz (VM, 4). 
bo droga jest uniwersalną metaforą życia i postępowania człowieka, powszechnie akceptowanym wyobrażeniem teleologicznej koncepcji ludzkiego istnienia, znaczonego wielostronnym wysiłkiem dążenia do doskonałości. Formowanie, wychowanie człowieka, paideię dawna kultura często przedstawiała jako proces, a konkretniej właśnie jako drogę, na ogół podzieloną na etapy czy stopnie, na której możliwe jest pozyskiwanie wiedzy o cnocie i sprawności w jej realizowaniu. Znajdziemy takie wyobrażenia w bliskiej poecie myśli sokratejskiej i platońskiej. Sokrates uzna w swym nauczaniu, że droga do celu, czyli bycia dobrym człowiekiem prowadzi przez cnoty tożsame z poznaniem prawdy, z mądrością; nie może na niej zabraknąć troski o duszę: samopoznania i pracy nad sobą. Jego uczeń Platon ukaże proces wychowania ludzi jako „drogę w górę”, równoznaczną z wyzwalaniem się z błędnych mniemań ku światłu prawdziwej wiedzy, a tym samym ku doskonałości poszczególnych osób i pomyślności państwa, a wreszcie ku najwyższemu Dobru ${ }^{22}$. Do idei drogi odwoływano się wyjątkowo chętnie w tradycji stoicko-cynickiej. Tu wiedzę o cnotach przekazują, na wzór Sokratesa, wędrowni nauczyciele, przedstawiający idealny obraz człowieka, który dzięki mądrości, głębszemu poznaniu siebie, a zwłaszcza praktykowaniu cnót powinien stawać się coraz doskonalszy. Chrześcijaństwo, jak wiadomo, prezentuje własny wariant tych paideutycznych praktyk w drodze. Ewangelie zawierają przecież wizerunek Jezusa jako wędrownego kaznodziei, niezmordowanego nauczyciela cnót chrześcijańskich, który sam jest ich wcieleniem, wzorem, drogą jako „droga i prawda, i życie" (J 14, 6). I w tradycji antycznej, i w tradycji chrześcijańskiej pojawia się także metafora dwóch dróg, z których jedna jest drogą cnoty, a druga - występku. W mitologii greckiej na rozstaju dróg staje Herakles ${ }^{23}$, zaś w nauczaniu chrześcijańskim ta sytuacja może stać się udziałem każdego, co świetnie obrazuje zarówno świat przedstawiony moralitetów, jak i szczegółowe katalogi cnót i występ-

22 Tym samym Sokrates, a następnie Platon obnażą płytkość sofistycznego nauczania cnoty, w którym dominował egalitaryzm i relatywizm (cnota jako zespół praktycznych umiejętności, potrzebnych do wykonania określonych zadań, i dostępny każdemu, kto podda się sofistycznej pedagogii). W Platońskiej Obronie Sokratesa bohater tak opisze swe działania na rzecz propagowania cnoty: ,Ja nic innego nie robię, tylko chodzę i namawiam młodych spośród was i starych, żeby się ani o ciało, ani o pieniądze nie troszczył jeden z drugim przede wszystkim, ani tak bardzo, jak o duszę, aby była jak najlepsza: i mówię im, że nie z pieniędzy dzielność rośnie, ale z dzielności pieniądze i wszelkie inne dobra ludzkie i prywatne, i publiczne". Cyt. wg: Platon, Obrona Sokratesa, w: tenże, Dialogi, thum. W. Witwicki, Warszawa 1988, s. 267.

${ }^{23}$ Przypowieść o Heraklesie, który na rozstajnych drogach spotyka Cnotę i Nieprawość, zostaje w ślad za sofistą Prodikosem z Keos, autorem Horai, przywołana przez KSENOFONTA w jego Wspomnieniach o Sokratesie (zob. tenże, Pisma sokratyczne, przeł. i wstępem poprzedził L. Joachimowicz, Warszawa 1967, s. 76-81). Dodajmy, że w ikonografii cnót postać Heraklesa często symbolizowała męstwo. 
ków, stosowane najpierw w stoickiej diatrybie, a następnie rozwijane w parenezie chrześcijańskiej (obecne już w Liście Barnaby i Didache) pod wpływem treści ewangelicznych: przypowieści o pannach mądrych i głupich, bramie szerokiej i wąskiej czy Kazania na górze. Ten typ myślenia i obrazowania podjęła również wielka epicka poezja drogi, zarówno ta przedchrześcijańska, jak i chrześcijańska. Dość powiedzieć, że i Homerowa Odyseja, i Boska komedia Dantego są osnute na motywie wędrówki bohatera, a zarazem w ten właśnie sposób unaoczniają dynamikę ludzkiego życia moralnego, zogniskowanego wokół praktykowania cnót. W eposie Homera zagadnienia etyczne powiązane zostają z próbą zobrazowania przemian społecznych: następuje kres epoki herosów i początek świata ludzkiego, historycznego, co pociąga za sobą zmierzch indywidualistycznego etosu, arystokratycznego pojmowania areté i zapowiedź kultury polis, z właściwymi jej moralnymi i prawnymi formami życia społecznego (jej zalążki widoczne są w scenie zgromadzenia ludu Itaki $)^{24}$. Natomiast Dante obrazuje kolejne stopnie moralnego postępu człowieka-chrześcijanina, jego wznoszenia się ku świętości, co jest równoznaczne z podjęciem tematu cnót i występków, a zwłaszcza z poetycką interpretacją cnót teologicznych (alegorycznie przedstawione Wiara, Nadzieja i Miłość $)^{25}$. Nie trzeba specjalnie przypominać, sugeruje to sam Norwid, że oba eposy, oczywiście w pewnym zakresie, patronują Vade-mecum i wydaje się, że zobrazowany w nich program moralny, zawarty w nich ideał aretologiczny nie jest dla poety bez znaczenia. W tym miejscu należy też raz jeszcze przywołać $P s y$ chomachię Prudencjusza, bo choć nie jest to poemat epicki oparty bezpośrednio na motywie drogi (wedle części badaczy to epos alegoryczny, pełen reminiscencji ze stoickiej diatryby i z poezji rzymskiej, a zwłaszcza Wergiliusza, inni kwalifikują go jako poemat alegoryczno-dydaktyczny, katechetyczny i ascetyczny), to jego akcja, poprzez kolejne walki cnót z wadami, nawiązującymi do grzechów głównych, odzwierciedla dynamiczny, agoniczny charakter życia moralnego oraz

${ }^{24}$ W myśl nowszych wykładni eposu: „Mury Troi są widocznym znakiem, swoistym słupem granicznym owego przełomu epok" (B. PATzeK, Homer i jego czasy, przeł. M. Tycner, Warszawa 2007, s. 99). Zob. też: E. HezA, Kryzys arystokratycznego pojęcia areté. Z badań nad historia myśli greckiej, „Etyka” 1972, s. 61-85. Ta opozycja epok i etosów wybrzmiewa w motcie Vade-mecum: Achilles przeciwstawiony zostaje Ulissesowi, ideały arystokratyczne - demokratycznym; istotny jest tu również egzystencjalny wymiar przeciwieństw - śmierć stanowi przeciwwagę dla życia postrzeganego jako wartość. Z sytuowaniem przez Norwida poezji Homera na granicy epok (tym razem między legendą a epopeją) mamy do czynienia również w Milczeniu (PWsz VI, 245).

${ }^{25}$ Program teologiczny i moralny Boskiej komedii obrazuje proces duchowego odrodzenia i zwycięstwa życia wiecznego nad śmiercią; wezwanie do kultywowania cnót to ważny jego aspekt psychagogiczny, duszpasterski. 
jego progres: w zakończeniu dzieła, po pokonaniu występków, cnoty pod przewodem Zgody i Wiary budują Chrystusowi świątynię, w której zasiądzie Mądrość.

Norwidowskie wyobrażenia drogi cnoty, ściśle powiązane z przeświadczeniem o pielgrzymiej kondycji człowieka i jego aspiracjach do osobowej pełni, sytuują się bez wątpienia w kontekście wskazanych powyżej tradycji kultury. Autor $\mathrm{Va}$ de-mecum postrzega podążanie drogą cnoty jako proces organicznego rozwoju, stopniowego dojrzewania człowieka do człowieczeństwa, dopełniania go w aktach kolejnych prób. U kresu tej drogi można osiągnąć stan symbolicznie reprezentowany przez ideę złotego wieku (mowa o nim w kontekście cnót w utworze Ironia: „Ty myślisz może, że wiek złoty,/ Bez walk, sam przyjdzie do ludzkości? - / A gdzież?... powiodą piérw te c n o ty; VM, 66) lub przez ,jabłoń-cnót" (jak w finalnej metaforze z utworu Zawody; VM, 75), co wydaje się wskazaniem na dobra osiągane dzięki praktykowaniu cnót, a w dalszej perspektywie, poprzez skojarzenie z drzewem życia, na eschatologiczne cele człowieka. Można więc powiedzieć, że drogę wieńczy osiągnięcie humanitas, humanitas christiana ${ }^{26}$. Kładąc nacisk na pozytywną rolę czasu w ludzkim wzrastaniu w cnocie, Norwid nie akceptuje oczywiście aktów przyspieszenia i rywalizacji czy zewnętrznych ingerencji, to temat poruszany w związku z problematyką cnoty w wierszach $\mathrm{Za}$ wody i Centaury, bo działania te z łatwością spychają człowieka z obranej drogi - w stan niedopełnienia, niedojrzałości, barbarzyństwa, adekwatnie zobrazowany przywołaniem postaci centaurów.

Jak widać, szczególnie ważną rolę problematyka cnoty odgrywa na poziomie refleksji antropologiczno-etycznej, rozwijanej w Vade-mecum. To trzeci poziom

${ }^{26}$ Ideał humanitas pojawia się, jak wiemy, bardzo często w literaturze rzymskiej, np. w pismach Cycerona. W szerokim polu znaczeniowym tego pojęcia znajdują się takie właściwości człowieka, odpowiedzialne za jego kulturę osobistą, jak uprzejmość, łagodność, życzliwość, mądrość, godność, wytworność, szlachetność, doskonałość. U autorów wczesnochrześcijańskich pojęcie to nabiera znaczenia moralnego, zakorzenionego w nauczaniu Chrystusa i przekazach ewangelicznych (obejmuje miłość bliźniego, dobroczynność, miłosierdzie). Jednak dopiero Prudencjusz, zwłaszcza w Psychomachii, stworzył wyrazistą koncepcję humanitas christiana, operując kanonem alegorycznie przedstawionych chrześcijańskich virtutes, wśród których znalazły się $\mathrm{m}$. in. wiara, nadzieja, skromność, cierpliwość, rozumność, pokora, powściągliwość, dobroczynność, zgoda. Zob. np. F. KLINGER, Humanität und Humanitas, w: Römische Geisteswelt, Hamburg-München 1961, s. 690-732; H. KuHN, Humanitas Christiana, w: Interpretationen der Welt. Festschrift Romano Guardini, hrsg. von H. Kuhn, Würzburg 1965, s. 151-171; W. PAWLAK, Z dziejów pojęcia „, humanitas” (do XVII wieku), w: Humanitas. Projekty antropologii humanistycznej, cz. 1: Paradygmaty - tradycje-profile historyczne, red. A. Nowicka-Jeżowa, Warszawa 2009-2010, s. 168-186; S. STABRYŁA, Humanitas Christiana w poezji Prudencjusza, w: Świadek Chrystusowych cierpień. Prace dedykowane Księdzu Profesorowi Adamowi Kubisiowi, Kraków 2004, s. 839-853. 
spójności cyklu, w wyznaczaniu którego uczestniczy wątek aretologiczny ${ }^{27}$. Aretologia jest bowiem ściśle powiązana $\mathrm{z}$ antropologią, paideia jest zawsze ukierunkowana na określony ideał człowieka, zaś powoływanie się w tym kontekście na cnotę wskazuje na ideał człowieka, określony przez areté, czyli „najlepszość" ${ }^{28}$. W antycznej grece słowo ,areté” jest synonimem maksimum zdolności i możności działania, efektywności, sprawności człowieka w dobroci ${ }^{29}$. A zatem chodzi tu o człowieka aspirującego do doskonałości, trwale zwróconego ku dobru, dążącego do jego osiągnięcia, mającego dobro samo w sobie, dobro najwyższe za cel swego istnienia.

Uwaga Norwida skoncentrowana jest w Vade-mecum na kilku cnotach. $\mathrm{Na}$ pierwszym miejscu znajduje się cnota męstwa, a nawet męstwa heroicznego, pierwotnie utożsamiana z areté, np. w Iliadzie Homera sławiącej czyny bohaterów odznaczających się siłą, odwagą, bojową skutecznością, arystokratycznym urodzeniem. Aretologia definiuje męstwo jako ogólną stałość umysłu człowieka, warunek każdej innej cnoty, lub jako szczególną sprawność znoszenia trudności i wytrwania wobec wszelkiego zła, w tym niebezpieczeństwa śmierci. Męstwo pozwala opanować odruch ucieczki, uzdalnia do atakowania przeciwnika i pokonania go, ale niekiedy pomaga też miarkować śmiałośśc ${ }^{30}$. Wydaje się, że dokładnie w tym duchu Norwid prowadzi swą poetycką interpretację cnoty męstwa. W wierszu Fatum męstwo, nie nazwane wprost, porównane tu do działań artysty ${ }^{31}$, pozwala stanąć oko w oko z nieszczęściem, wytrzymać jego napór

${ }^{27}$ Władysław Strożewski, interpretując Vade-mecum jako wyraz Norwidowej filozofii człowieka, eksponuje przede wszystkim metaforę człowieka-pielgrzyma, który pozostaje in statu viae. Droga, którą przemierza, daje szansę pozyskania fundamentalnych atrybutów osoby. Wiedzie ona, poprzez trud, ku pełni osobowego bytu, ku ludzkiej doskonałości, samoświadomości, kapłańskiej dojrzałości, wolności, prawdzie, transcendencji. W tej przekonującej i inspirującej analizie poetyckiej antropologii Norwida nie znajdujemy jednak odniesień do problematyki aretologicznej. Zob. W. StróżEwski, Filozofia człowieka w ,,Vade-mecum ” Cypriana Norwida, w: tenże, O wielkości. Szkice z filozofii człowieka, Kraków 2002, s. 7-27.

28 Słowo ,areté” pochodzi od słowa ,áristos”, czyli stopnia najwyższego od ,agathós”, tzn. „dobry”; najwierniej oddaje je więc słowo „najlepszość”.

29 Zob. Z. PAŃPuch, Areté, s. 318-325; S. Witek, H. Wegner, Cnota, w: Encyklopedia katolicka, t. III, Lublin 1979, szp. 521-527; F. GryGLEwICZ, H. WeGner, Cnót katalogi, w: Encyklopedia katolicka, red. zbior., t. III, Lublin 1979, s. 527-530; Cnoty $i$ wady [hasło], w: Stownik teologii biblijnej, red. X. Leon-Dufour, przeł. i oprac. bp K. Romaniuk, Poznań 1990, s. 160-162.

30 Zob. Z. PAŃpuch, Męstwo, w: Powszechna encyklopedia filozofii, t. VII, Lublin 2006, s. $140-143$.

31 W twórczości Norwida artysta uzyskuje status bohatera kulturowego, herosa. Pisałam na ten temat szerzej w artykule pt. Norwidowskie miary i oglady heroizmu („Kultura Słowian. Rocznik Komisji Kultury Słowian PAU”, Kraków 2018, s. 113-133). 
i w końcu odnieść nad nim zwycięstwo, które jest zarazem zwycięstwem człowieka mężnego nad samym sobą ${ }^{32}$. Z kolei w wierszu Cnót-oblicze cnota tragiczna ma u swych podstaw mężne przezwyciężanie oporu: „Od hardych mieczów - do krzyżowych ćwieków; / Od więzień - pod sznur i topór" (VM, 86). Natomiast Bohater zawiera swoistą rekapitulację dziejów męstwa: od mitu o wyprawie Argonautów, przez heroizm Mojżesza i męstwo chrześcijan, widziane w świetle zarówno śmierci-ofiary Chrystusa jak i chrześcijańskiej słodyczy, nie przeciwstawianej bynajmniej dawnej cnocie, lecz traktowanej jako jej duchowe dopełnienie: „ona raczej - jako białogłowa / Wierna - współzwycięża duchem!" (VM, 120), aż po dziewiętnastowieczną postać heroizmu, czyli pracę. Poeta przedstawia w tym wierszu męstwo heroiczne jako jeden $\mathrm{z}$ uniwersalnych wątków ludzkiej historii, jako jeden z kluczowych czynników „zaciągu-dziejów”. Pisze: „Bohaterowie wszak od wieków w wieki / Kraj zdobywają z a k 1 ę t y -” (VM, 119) i można chyba dodać, że wedle Norwida powinni to czynić w postawie męstwa po kres czasu.

Drugą cnotą kardynalną eksponowaną w obrębie antropologicznego planu Vade-mecum jest umiarkowanie, a więc zespół atrybutów, które starożytni określali mianem sóphrosyné, mając na myśli poczucie umiaru, roztropność, dyscyplinę i równowagę wewnętrzną, umiejętność trzymania się w działaniu drogi pośredniej między skrajnościami. Właściwe działanie wymaga bowiem proporcjonalności i miary w stosunku do dobra obranego jako cel; miara powinna uwzględniać nie tylko naturę przedmiotu, ale i podmiotu działania. Zarówno nadmiar jak i niedomiar aktywności w stosunku do dobra uniemożliwiają jego osiągnięcie i są przyczyną rozlicznych wad. Kwintesencją cnoty umiarkowania, w różnych jej interpretacjach, staje się więc ideał panowania człowieka nad sobą, nieulegania siłom natury, a poddania pożądliwej części duszy, czyli afektów, namiętności, również zmysłów, pod porządkującą władzę rozumu (logosu) jako dysponenta miary $^{33}$. Temat to, można śmiało powiedzieć, specyficznie Norwidowski i z pew-

32 Józef Fert w komentarzu do utworu eksponuje motyw próby, doświadczania, „badania” nieszczęścia, uznając go za istotny, powtarzalny składnik „Norwidowskiego poglądu na temat powołania artysty-myśliciela-odkrywcy" (VM, 58). Wśród kontekstów słusznie wymienia Rozmyślania Marka Aureliusza (VIII, 28), które - dodajmy - są sekwencją stoickich ćwiczeń duchowych, mających na celu m. in. kształtowanie człowieka cnotliwego.

33 W Państwie Platona Sokrates stwierdza, że umiarkowanie jest to „pewien ład i wewnętrzne panowanie nad przyjemnościami i nad żądzami, jak się to mówi. Mówi się przecież o mocy nad sobą [...]”. A dalej objaśnia sens zwrotu ,panowanie nad sobą”: ten zwrot znaczy to, że „w samym człowieku, w jego duszy, jest pewna cząstka najlepsza i inna, gorsza. I kiedy to, co z natury lepsze, panuje nad tym, co gorsze, to znaczy, że człowiek panuje nad sobą i to się chwali [...]” (430 E - 431 A). Cyt. wg: Platon, Państwo, tłum. W. Witwicki, Warszawa 1991, t. 1, s. 203. 
nością godny gruntownego opracowania w oparciu o szerszą podstawę tekstową. Tymczasem chciałabym zwrócić uwagę jedynie na wiersz Królestwo, w którym autor symbolicznie stawia człowieka na rozstaju dróg, między skrajnościami: wolnością, przybierającą postać niepohamowanego indywidualizmu, a niewolą małoduszności, która sprowadza ludzkie istnienie na poziom istnienia zwierzęcego. W zakończeniu utworu Norwid proponuje trzecią drogę:

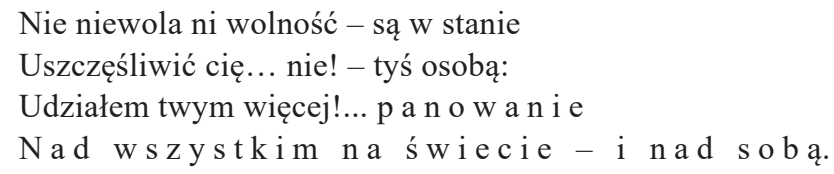

Ta poetycka proklamacja personalizmu, królewskiej godności człowieka jako osoby, zawiera czytelne odniesienia do cnoty umiarkowania. Panowanie nad stworzeniem zostaje zintegrowane $\mathrm{z}$ ideałem panowania nad sobą, czyli zdolnością do przekraczania wszelkich determinacji natury wewnętrznej, ale też presji społecznej, co wymaga mocy i szlachetności woli, a nade wszystko doskonałości duchowej, polegającej na respektowaniu władzy rozumu i prawa ${ }^{34}$.

Norwid czyni w Vade-mecum aluzje również do cnoty sprawiedliwości, tym samym jego poetycka aretologia dotyka zagadnień życia wspólnotowego. Sprawą publiczną uczynili cnotę myśliciele starożytni, upatrujący w niej zasadniczej kategorii życia społecznego. Jak wiemy, Platon i Arystoteles, poszerzając znaczenie areté, postawili sprawiedliwość na czele cnót obywatelskich. Według autora Uczty na sprawiedliwości opiera się nie tylko współbrzmienie sił duchowych człowieka $^{35}$, ale też harmonia między wnętrzem człowieka a politycznymi strukturami państwa, będącego przestrzenią umożliwiającą ludziom prowadzenie prawdziwego życia. Z kolei Arystoteles, widząc w człowieku istotę społeczną, uzna funkcjonowanie w ramach polis za konieczny kontekst ludzkiego bytowania, za ważny, niezbywalny etap doskonalenia człowieka, a to ze względu na wychowawczą rolę polis. Norwid niewątpliwie w dialogu z tą szeroko znaną tradycją intelek-

${ }^{34}$ W wierszu (W pamiętniku), stanowiącym część Prologu Tyrteja, idea panowania nad sobą zostaje powiązana z sytuacją próby i samopoznania: „Wtedy to próba jest, wtedy jest waga, / Ile? nad sobą wziąłeś panowania; / Wartość się twoja ci odsłania naga - / I oto widzisz, ktoś-ty? ... bez pytania" (DW VI, 17).

${ }_{35}$ Człowiek sprawiedliwy to taki, który ,urządził sobie gospodarstwo wewnętrzne, jak się należy, panuje nad sobą, utrzymuje we własnym wnętrzu ład, jest dla samego siebie przyjacielem; zharmonizował swoje trzy czynniki wewnętrzne [chodzi o trzy „,części” duszy: rozumną, impulsywną i pożądliwą - A. Z.], jakby trzy struny dobrze współbrzmiące [...] i stał się ze wszech miar jedną jednostką, a nie jakimś zbiorem wielu jednostek”. Zob. Platon, Państwo (443 C-E), t. I, s. 228. 
tualną nadaje w Vade-mecum cnocie sprawiedliwości status czynnika kształtującego relacje międzyludzkie, przenikającego życie obywatelskie, gwarantującego harmonię społeczną. Ideał wspólnoty politycznej, zorganizowanej wokół tak rozumianej cnoty sprawiedliwości, wyłania się z wiersza Ideat i reformy. Pojecie cnoty jest tu elementem języka i światopoglądu Monarchy-Mędrca ${ }^{36}$, porównanego do Trajana i Marka Aureliusza, a zatem do cesarzy wybitnych i zasłużonych, społecznego reformatora i wybitnego filozofa, który w swych Rozmyślaniach daje (także sam sobie) wykład stoickiego pojmowania cnoty i określa sposoby ćwiczenia się w niej, tzn. stopniowego osiągania moralnej doskonałości, aż po jej pełne wcielenie w roli władcy idealnego. Monarcha ów w przytaczanej w wierszu mowie konstatuje wśród obywateli niedostatek areté, rozumianej jako podstawa ładu społecznego i społecznej wzajemności oraz jako potencjalne źródło potęgi politycznej państwa. Jego wypowiedź wydaje się wyrazem przeświadczenia o niemal nieosiągalności stanu równowagi między cnotą filozoficzną a cnotą polityczną, między poznaniem a działaniem ${ }^{37}$. Trzeba jednak zaznaczyć, że Monarcha żali się na obywateli „w swej warowi i w kraju podbitym”, a to z kolei może być bezpośrednią aluzją do biografii Marka Aureliusza, który w okresie swego panowania więcej czasu spędzał na krwawych wojennych wyprawach niż w Rzymie, ale może też sugerować, iż cień ironii pada na aretologiczne uwagi Monarchy - agresora i tyrana, w istocie odizolowanego od rzeczywistości społecznej, wyobcowanego w swej „twierdzy wewnętrznej”. Nie pozbawione zasadności jest również interpretowanie tej postaci przez pryzmat motta cyklu: w swej skardze umarły Achilles odrzuca los Monarchy, panującego ,nad narodem umarłych” (VM, 3). Po raz kolejny trudno o interpretacyjną precyzję, bo utwór nie zachował się w całości ${ }^{38}$.

${ }^{36}$ Na marginesie odnotujmy, że przedstawienia cnót stanowiące element zdobień na kolumnach Trajana i Marka Aureliusza w Rzymie stanowiły źródło ilustracji do Psychomachii.

37 Wśród notatek cesarza znajdujemy zapis: „Nie spodziewaj się nadejścia rzeczypospolitej Platońskiej. Lecz bądź zadowolony, jeżeli choć krok robisz najmniejszy. I bądź tego przekonania, że w tym wypadku nic nie jest małe" (9. 29). Cyt. wg: MareK Aureliusz, Rozmyślania, przeł. M. Reiter, Warszawa 1984, s. 110. Słowa te są unaocznieniem wątpliwości autora, jego wewnętrznego rozdarcia, a nawet utraty przezeń złudzeń co do szans na osiągnięcie doskonałości w dziedzinie polityki, na harmonijne zespolenie roli filozofa i władcy. Zob. M. DzIELsKA, Idee polityczne Marka Aureliusza, w: Teoria i praktyka polityczna Marka Aureliusza, red. K. Marulewska, Warszawa 2010, s. 81-93.

38 Przykładów Norwidowskich zainteresowań cnotą, powiązaną z powinnościami społecznymi, z działaniami dla dobra wspólnego, dostarczają również inne utwory poety. Tu odnotuję jedynie fascynację Norwida osobą Tyrtajosa. Ten ,prorok cnoty”, jak określał go W. JAEGER (Paideia. Formowanie człowieka greckiego, s. 58), nadający jej walor polityczny, obywatelski, patriotyczny, niepokoił wyobraźnię Norwida na tyle skutecznie, że w Tyrteju doszło do istotnej, także w perspektywie refleksji aretologicznej, rewizji legendy, osnutej wokół jego działań przywódcy i poety. 
I w końcu trzeba koniecznie powiedzieć o jeszcze jednej cnocie, która w poetyckiej aretologii Norwida odgrywa rolę wyjątkowo ważną. To oczywiście kalokagathia, czyli dobro-piękno, cnota, która w tradycji antycznej stanowiła zwieńczenie wszystkich cnót, ich pełnię, była bowiem oznaką szlachectwa duszy ludzi najlepszych oraz najwyższym ideałem wychowawczym kultury, akcentującym zalety moralne człowieka, skierowane na cel sam w sobie, na dobro samo w sobie (w odróżnieniu od dobra przyjemnego czy użytecznego). We wczesnej tradycji chrześcijańskiej pozostającej pod wpływem kultury greckiej zachowano pojęcie „kalokagathia”, dołączając doń wiarę i miłość, a także wiedzę objawioną (np. ojcowie kapadoccy, Klemens Aleksandryjski) ${ }^{39}$.

W kręgu kalokagathii autor Vade-mecum sytuuje postać i twórczość Chopina jako artysty ucieleśniającego ideał sztuki, jej dojrzałość i doskonałość. W Fortepianie Szopena osobowe piękno artysty (sugerowane obrazem ręki „białości alabastrowej”, delikatnych dotknięć klawiatury - ,jak strusiowe pióro”, zachowań pełnych ,i wzięcia, i szyku" ${ }^{40}$ ), przedstawione zostało jako źródło sztuki będącej wyrazem cnoty, wręcz mową cnoty. Norwid ukazuje akt twórczy muzyka jako osiąganie ideału „doskonałości Peryklejskiej”, a zatem będącego wedle

39 Jak wiadomo, rozwojowi religii chrześcijańskiej w pierwszych wiekach jej istnienia towarzyszy nieprzerwany proces interpretacyjny, w którym religia hebrajska przedstawiana jest w kategoriach filozofii greckiej. Pomimo odrębności języków, widoczne staje się ich wzajemne przenikanie, aż po symbiozę myśli helleńskiej i wczesnochrześcijańskiej w intelektualnych kręgach Aleksandrii. W tym procesie „thumaczenia” pojęć i idei pojawiają się także terminy areté, kalokagathia i paideia, dzięki czemu w nawiązaniu do tradycji greckiej tworzone są podwaliny chrześcijańskiej aretologii i koncepcji nauczania cnót. Zob. W. JAEGER, Early Christianity and Greek Paideia, Harvard 1962. O formowaniu się pojęcia kalokagathia i jego różnych zakresach znaczeniowych pisze: P. JAROSZYŃSKI, Kalokagathia, w: Powszechna encyklopedia filozofii, t. V, Lublin 2004, s. 444-447.

${ }^{40}$ Intrygujące piękno osobowe Chopina niejednokrotnie stanowiło przedmiot refleksji Norwida - zwłaszcza w Czarnych kwiatach, gdzie skupiał się na pięknie postaci artysty: „On, w cieniu głębokiego łóżka z firankami, na poduszkach oparty i okręcony szalem, piękny był bardzo, tak jak zawsze, w najpowszedniejszego życia poruszeniach mając coś skończonego, coś monumentalnie zarysowanego... coś, co albo arystokracja ateńska za religię sobie uważać mogła w najpiękniejszej epoce cywilizacji greckiej - albo to, co genialny artysta dramatyczny wygrywa np. na klasycznych tragediach francuskich [...]. Taką to naturalnie apoteotyczną skończoność gestów miał Chopin, jakkolwiek i kiedykolwiek go zastałem...” (DW VII, 47). Oczywiście poeta próbował zrozumieć arystokratyzm wyglądu i ducha, geniusz Chopina, wnikając w jego muzykę, w ,jej formę (w najszerszym rozumieniu tego słowa) i bogactwo duchowych doświadczeń, które się w niej wyraża. Te dwa ideały: doskonałości formalnej i wielkości ducha były także najbliższe Norwidowi" (zob. W. StróżEwSKi, Chopin i Norwid, w: tenże, Wokół piękna. Szkice z estetyki, Kraków 2002, s. 292). Zauważmy, że są to ideały, które sytuują postać Chopina w dominium cnoty jako drogi do doskonałości i wielkości człowieka. 
Greków ucieleśnieniem najwyższej doskonałości w sztuce, która nie jest jedynie wartością estetyczną, bo jest także wartością moralną: piękno zsyntetyzowane $\mathrm{z}$ dobrem to podstawa kalokagathii. Nie dziwi zatem pojawienie się w tym kontekście starożytnej Cnoty, synonimu doskonałości. W obrębie porównania zawierającego soliloqium Cnoty okazuje się ona doskonałością „ochrzczoną”, „odrodzoną w Niebie”, przeobrażoną w świetle chrześcijańskich tajemnic wiary Eucharystii i Przemienienia ${ }^{41}$. W ten oto sposób w obrębie wizji, której podmiotem jest Cnota, unaocznione zostaje „D o s k o n a ł e - w y p e łn i e n i e”, mające postać symbolicznego (sakramentalnego) pojednania człowieka i Boga, ziemi i nieba, czasu i wieczności, tego, co duchowe i tego, co materialne ${ }^{42}$, a będące także formą zintegrowania pierwiastków narodowych („I była w tém Polska - od zenitu / Wszechdoskonałości dziejów / Wzięta tęczą zachwytu / - Polska - p r z e m i e n i o n y c h k ołodziejó w"; VM, 160) i ogólnoludzkich, partykularnych, ludowych (sugerowanych przez „dom modrzewiowy wiejski”, do którego wchodzi starożytna Cnota) i uniwersalnych, humanistycznych i religijnych, chrześcijań$\mathrm{skich}^{43}$. Moment ten Norwid przedstawia jako zarazem zwieńczenie wędrówki drogami cnoty: wartości wypracowane przez ludzkość podlegają zsyntetyzowaniu, duchowej przemianie, przeniesione na poziom sacrum, sięgają eschatologicznej pełni:

${ }^{41}$ Warto przypomnieć, że przyswajanie elementów filozofii greckiej (w rozpatrywanym przypadku chodzi o cnotę) przez chrześcijaństwo łączy się niekiedy ze stwierdzeniem ich podobieństwa i zarazem różnicy poziomów wiedzy: chrześcijaństwo przedstawiane jest jako filozofia, ale philosophia Christi górująca nad filozofią Greków, jako „mądrość Boża”, ale przezwyciężająca „mądrość świata” i „mądrość pogan” (Kor 1, 21-25). Starożytna kultura intelektualna staje się więc przygotowaniem do przyjęcia prawdy Ewangelii (praeparatio evangelica). Myśleniu w kategoriach podobieństwa sprzyja też charakter filozofii w epoce hellenistycznej - spełnia ona często funkcje religijne, bo filozofowie chcą kierować ludzkim życiem i oczekują od adeptów swych nauk praktycznego zastosowania zaleceń. Zob. J. DoMAŃski, Chrześcijaństwo a filozofia grecka, „Znak” 1992, nr 1, s. 58-66.

${ }^{42}$ W Norwidowym rozumieniu kalokagathii jej źródłowy, starożytny sens oczywiście interferuje z nowożytnymi interpretacjami tej kategorii (Shaftesbury, Winckelmann, Schelling, Hegel), uznającymi jedność ducha i materii za szczególnie ważny jej aspekt.

${ }^{43}$ Władysław STRóżEwSKI w swej interpretacji Fortepianu Szopena (Doskonałe-wypetnienie. O „,Fortepianie Szopena” Cypriana Norwida, „Pamiętnik Literacki” 1979, z. 4, s. 43-72) rozumie „D o s k o n a ł e-w y p e łn i e n i e” jako efekt procesu przemiany, dynamicznego rozwoju, syntetyzowania wartości, co w momencie osiągnięcia absolutnego optimum jest równoznaczne $\mathrm{z}$ aktualizacją ideału w sztuce, $\mathrm{z}$ aksjologiczną jednością różnych rodzajów wartości (wartości estetyczne zostają zintegrowane z wartościami moralnymi, religijnymi), ze stopieniem się artysty z dziełem. 
Odrodziłam się w Niebie

I stały mi się Arfą-wrota,

W s tę gą-ś c i e żk a...

Hostię-przez blade widzę zboże...

Em anuel już mieszka

$\mathrm{Na} \mathrm{Tab}$ orze!

(VM, 159)

Jest to oczywiście droga niezwykle karkołomna, bo przecież „Piętnem globu tego - niedostatek", jednak wielka sztuka, a zwłaszcza wielka muzyka, jako wypełnienie ideału kalokagathii ${ }^{44}$, może być cennym drogowskazem, bo w swych genialnych wytworach artysta jest w stanie odsłaniać nadrzędny cel wędrowania. Władysław Stróżewski, pisząc o ideach cykliczności i drogi w Vade-mecum, podkreślał wyjątkowe w tym kontekście znaczenie Fortepianu Szopena: „Utwór ten stanowi niewątpliwie kulminację cyklu. Droga, a raczej wielość polifonicznie prowadzonych dróg, dochodzi tu do kresu, będącego prawdziwym, ale jakże dramatycznym jej dopełnieniem. Utwór ostatni, owo cudowne Na zgon Józefa Z brzmi już jak błogosławieństwo, udzielone w największej ciszy i skupieniu stojącemu u progu wieczności wędrowcowi” ${ }^{45}$. Nie sposób oprzeć się przeświadczeniu, iż w kreowaniu tego punktu szczytowego Vade-mecum ważną rolę odgrywa wątek aretologiczny.

Lektura Vade-mecum w perspektywie Norwidowskiej aretologii uświadamia, jak głęboko zanurzone jest w tradycjach filozoficzno-religijnych myślenie poety o cnocie. Sokrates, Platon, stoicy i cynicy wydają się głównymi przewodnikami Norwida po świecie cnoty starożytnej. Oczywiście Norwid łączy ich idee z chrześcijańskim postrzeganiem cnoty. To problematyka wciąż żywa przecież w nauczaniu Kościoła w XIX wieku ${ }^{46}$, a zarazem mocno osadzona w chrześcijańskiej tradycji intelektualnej i duszpasterskiej, będącej przedmiotem żywych zainteresowań poety. Dość przypomnieć Ojców Kościoła, ze św. Tomaszem na

${ }^{44}$ Warto przypomnieć, że w Państwie (401 D-402 A) Platon kojarzy kalos kai agathós z wychowaniem, którego podstawę stanowi muzyka. Jej rytm i harmonia kształtują duszę człowieka w sposób właściwy, kierując ją ku dobru i pięknu.

45 W. STróżewski, Chopin i Norwid, s. 301.

${ }^{46}$ Co więcej, problem cnót jest w II poł. XIX wieku na tyle żywo dyskutowany, że w 1899 roku papież Leon XIII w encyklice Testem benevolentiae nostrae potępia pogląd (tzw. amerykanizm), głoszący wyższość cnót czynnych nad kontemplacyjnymi i przyrodzonych nad nadprzyrodzonymi. 
czele, przedstawiającym w Summie teologicznej wielką syntezę aretologiczną, obejmującą trzy cnoty teologiczne, pięć sprawności intelektualnych i cztery cnoty kardynalne, a zbudowaną w oparciu o treści objawienia, ale także etykę starożytnych: Arystotelesa, stoików, neoplatoników, oraz myśl chrześcijańską: patrystyczną, monastyczną, scholastyczną ${ }^{47}$. Z pewnością ważne były dla Norwida-aretologa również źródła literackie, zwłaszcza Homer, czyli - jak twierdził Platon - „wychowawca całej Grecji” (Państwo, $606 \mathrm{E}$ ) w duchu areté, a także Dante przedstawiający swą wersję drogi człowieka przez piekło i czyściec ku niebu, czyli ku duchowemu odrodzeniu, dobru, Bogu, czy wreszcie, dotychczas nie odnotowywany w kontekstach dzieł poety, Prudencjusz, kształtujący w swej Psychomachii bardzo trwały model obrazowania walki cnót z występkami, który staje się następnie uniwersalnym modelem życia chrześcijańskiego, zobrazowaniem humanitas christiana. Wyobraźnia aretologiczna Norwida zapewne wiele zawdzięcza również plastycznym przedstawieniom cnót. Pod wpływem Prudencjusza rozwija się przecież bardzo bogata ikonografia psychomachii, utrwalana najpierw w ilustrowanych rękopisach jego dzieła (IX-XIII w.), a potem przenikająca do malarstwa, rzeźby (często rzeźby sepulkralnej), sztuki witrażu, architektury. Norwid mógł prowadzić regularne studium tego zjawiska w czasie swego pobytu we Włoszech, choćby w Toskanii, bo tu wybitni artyści, tacy jak Giotto di Bondone, Pisano, Donatello, Lippi, Luca della Robia szczególnie chętnie sięgali po ten typ obrazowania, wykorzystując przy tym w niektórych przypadkach inspiracje płynące z Boskiej komedii. Również we Francji, w której poeta spędził wiele lat życia, ikonografia cnót jest wyjątkowo rozpowszechniona, przede wszystkim w plastyce katedralnej (najbardziej spektakularny portal katedry Notre-Dame w Paryżu, obrazując Porta Dei, Porta Paradisum, przedstawia Chrystusa w momencie Paruzji w otoczeniu apostołów, proroków i męczenników oraz dwunastu tronujących cnót, a dodajmy, że cykl ten został następnie powtórzony w katedrach w Amiens i Chartres; zaś w opactwie w Cluny oraz katedrze w Strasburgu podjęto motyw walki cnót z występkami ${ }^{48}$. Wydaje się, że kobiece personifikacje cnót, wizje triumfu cnoty, jabłoni cnót jako wariantu bardzo popular-

${ }^{47}$ Zob. św. Tomasz z Akwinu, Traktat o cnotach. ,, Summa teologii” I-II, 49-67, thum. W. Galewicz, Kęty 2006.

48 Zob. S. WiteK, H. Wegner, Cnota, s. 523-527; M. U. MazurCZaK, Spes-nadzieja pośród personifikacji cnót. Wokót Andrei Pisana drzwi południowych baptysterium we Florencji, „Ethos” 2010, nr 92, s. 183-199. Dodajmy, że w Polsce ze szczególnie bogatą ikonografią cnoty zetkniemy się w Katedrze Wawelskiej (krypta św. Leonarda, sarkofagi i pomniki grobowe władców), a także w kościołach św. Anny w Krakowie, św. Andrzeja w Olkuszu, Św. Trójcy w Strzelnie (program ikonograficzny odwołujący się do wizji drzewa cnót i drzewa przywar). Jest to też ikonografia obecna w wielu rezydencjach świeckich, królewskich czy magnackich. 
nego przedstawienia kwitnącego drzewa cnót (przeciwwagę tworzyło uschnięte drzewo wad), czy ścieżki, która staje się wstęgą (tzn. znakiem pojednania, ale może też banderolą z alegorii cnót) można rozpatrywać właśnie w kontekście plastycznych doświadczeń autora Vade-mecum.

Wprowadzając do swego języka poetyckiego i świata myśli pojęcie cnoty, Norwid staje w opozycji do refleksji etycznej swych czasów, może nawet wydawać się na jej tle anachroniczny. W etyce XIX stulecia współistnieją bowiem w dyskursie moralnym różne poglądy o proweniencji nowożytnej, często oświeceniowej. Ogromne znaczenie uzyskuje wówczas emotywizm (jego źródłem jest myśl Davida Hume'a), w świetle którego moralność, oparta na arbitralnym, irracjonalnym akcie wyboru autonomicznego podmiotu, okazuje się ekspresją namiętności, uczuć, upodobań, egoizmu. Jak wiadomo, przeciwstawiał się tej tendencji Immanuel Kant i kontynuatorzy jego myśli, poszukując powszechnej zasady postępowania moralnego i uznając, że maksyma, która wyraża prawo moralne i determinuje wolę nie może być zakorzeniona ani w dążeniu do szczęścia, ani w Bogu. Rezygnując z treści moralnej imperatywu, królewiecki filozof wybiera autonomię podmiotu moralnego, ale zarazem etyczny formalizm, będący próbą ufundowania moralności na samym rozumie. Pokantowski formalizm ściera się w XIX wieku z różnymi postaciami utylitaryzmu (Jeremy Bentham, John Stuart Mill), akcentującego znaczenie szczęścia, postrzeganego przez pryzmat użyteczności, skuteczności, sumy różnorodnych korzyści, do których ludzie pragną dążyć w swym życiu. I etyczny kantyzm, i utylitaryzm znajdują u schyłku stulecia żarliwego przeciwnika w osobie Friedricha Nietzschego, który odrzucając wszelkie koncepcje moralności uzasadniane racjonalnie lub eudajmonistycznie proklamuje woluntaryzm i moralny solipsyzm, a w istocie nihilizm.

Przywołane powyżej główne tendencje dziewiętnastowiecznej refleksji etycznej trudno uznać za bliskie Norwidowi. Przeciwnie, ich myślowe podstawy i praktyczne przejawy były przez poetę wielokrotnie krytykowane jako redukujące, instrumentalizujące ludzką godność. A zatem trwanie Norwida przy klasycznej etyce cnót należy uznać za wybór w pełni intencjonalny, mieszczący się w ramach jego polemiki ze współczesnością, będący ważnym argumentem w batalii przeciw degeneracji człowieka epoki ${ }^{49}$. Jest to z pewnością wybór chrześcijanina, przeko-

49 Znamienne, że współcześni krytycy nowożytnej teorii moralności konfrontują etykę oświeceniową i pooświeceniową, a zatem tę, której niedostatki przenikliwie diagnozował Norwid, z tradycją arystotelesowsko-tomistyczną, bo dostrzegają w kluczowej dla niej koncepcji cnót potencjalne źródło odnowy moralności, wychowania człowieka, kultury. W pracach głoszących potrzebę powrotu do etyki cnót chodzi przede wszystkim o przywrócenie, w miejsce dominującego obecnie emotywizmu, teleologicznego schematu działania moralnego (dobro jako nadrzędny cel; związek między cnotą, szczęściem a dobrem czy też Bogiem) oraz obiektywnych, racjonalnych uzasadnień 
nanego o znaczeniu cnót w kodeksie moralności chrześcijańskiej, a jednocześnie świadomego antycznej genealogii areté. Jest to też wybór personalisty, bo kategoria cnoty współgra z koncepcją osoby jako synonim jakości ludzkiej duszy oraz czynnik osobowej doskonałości człowieka i jego sprawności moralnej w działaniu. Zarazem wyznacza ona potencjalne pole do dyskusji z dziewiętnastowiecznym indywidualizmem, z dziewiętnastowiecznymi koncepcjami ludzkiej podmiotowości, eksponującymi znaczenie czysto subiektywnych uczućc ${ }^{50}$, a zatracającymi ideę podmiotu moralnego i wewnętrznie zintegrowanego, respektującego przy tym obiektywny punkt odniesienia dla Ja. Polemika obejmować może także zrodzone w ówczesnej kulturze indywidualizmu koncepcje życia zbiorowego, które przystając na wizję społeczeństwa jako sumy egoizmów, abstrahują od tradycyjnego uznawania cnót za ostoję życia wspólnotowego lub choćby tylko za czynnik stabilizujący relacje międzyludzkie. Jest to też wybór krytyka współczesnej sobie kultury, w której zdaje się nie ma już miejsca dla cnoty, bo „nie czas myśleć... o cnocie!”, jak czytamy w Larwie (VM, 36), bo od cnoty ,cofa strach śmieszności”, w myśl frazy pochodzącej z Ironii (VM, 66). Norwid dokonuje zatem w swej poezji aktu rewindykowania znaczenia cnoty w roli także czynnika kulturotwórczego, co jest równoznaczne z przywołaniem, na zasadzie ideału, wizji kultury jako środowiska formowania człowieka ku najwyższym wartościom. Wedle Norwida najpełniej realizuje ten ideał Chopin, ale dodajmy, sam poeta stara się wcielać go swą twórczością w życie.

moralności, które czerpałyby z koncepcji prawdy, wyłożonej przez Arystotelesa (prawda jako adekwatność umysłu wobec jego przedmiotów), a następnie zdefiniowanej przez św. Tomasza jako adaequatio rei et intellectus. Tak więc formułowana jest w tych dyskusjach etycznych propozycja wyjścia w filozofii moralności poza granice relatywizmu indywidualistycznego i kulturowego. Scharakteryzowany powyżej punkt widzenia wielokrotnie prezentował w swych głośnych i szeroko komentowanych publikacjach jeden z przedstawicieli anglosaskiej etyki cnót Alasdair MACINTYRE (zob. np. Whose Justice? Which Rationality? Notre Dame 1988; First Principles, Final Ends and Contemporary Philosophical Issues, Milwaukee 1990; Dziedzictwo cnoty. Studium z teorii moralności; Dependent Rational Animals. Why Human Beings Need the Virtues, Chicago 1999). Również we współczesnej teologii podejmowane są próby powrotu do uznania problematyki aretologicznej za ośrodek refleksji etycznej, co oznacza ponowne odkrycie walorów tomistycznej nauki o cnotach (zob. ks. L. Melina, Problematyka cnoty we współczesnej teologii moralnej, przeł. P. Mikulska, „Ethos” 2011, nr 9, s. 61-77). Należy odnotować, że w tym swoistym renesansie myślenia w kategoriach cnoty uczestniczy też współczesna teoria kultury (zob. I. CHŁODNA-BŁACH, Od paidei do kultury wysokiej. Filozoficzno-antropologiczne podstawy sporu o kulture, Lublin 2016).

${ }^{50}$ Norwid jest przekonany, że we współczesnej mu kulturze emocje nierzadko podszywają się pod cnoty. W kontekście uwag na temat prasy padają słowa: „udramatyzowane zręcznie pasje mogą otrzymywać efekta do cnót podobne” (List do Władysława Czartoryskiego, Paryż, 20 lutego 1863; PWsz IX, 80). 
Vade-mecum jest oczywiście zdominowane przez postawę ironicznego krytycyzmu autora, ale nie sposób nie zauważyć, że wątek aretologiczny ma jednak u swych podstaw afirmację - afirmację trudu dążenia do cnoty i życia wedle cnót, pomimo wszystko i wbrew wszystkiemu, bo jest to jedyna droga stawania się osobą, jedyna droga prowadząca do pełni człowieczeństwa. Przypomnijmy: w klasycznej teorii cnót chodziło właśnie to, by człowiek, wyposażony w odpowiednie intelektualne i moralne sprawności, mógł poprzez czyn udoskonalać swe życie osobowe, wewnętrzne, duchowe, a zarazem by był gotów jak najlepiej sprawować przypisane mu role społeczne i działać dla dobra wspólnego. U Norwida ton afirmacji o proweniencji aretologicznej obejmuje też, jak sądzę, pewien typ działań poetyckich, a mianowicie postawę poety-moralisty, który uprawia poezję rozumianą jako droga formowania w odbiorcach cnoty, jako zachęta do ćwiczenia się w cnocie, to znaczy uprawia poezję ściśle powiązaną z dobrem, indywidualnym i zbiorowym, a finalnie prowadzącą do Dobra jako swego nadrzędnego celu.

Po lekturze Vade-mecum z pewnością trudno o jednoznaczne, precyzyjne określenie pozytywnego programu Norwida, ale - jak można sądzić - uwzględnienie problematyki aretologicznej sprawia, że przynajmniej pewne aspekty tego programu stają się lepiej widoczne. Wokół kategorii cnoty krystalizuje się bowiem krąg ważnych zagadnień etycznych, będących próbą mentorskiej, psychagogicznej odpowiedzi Norwida na trapiący ludzkość niedostatek. Odsłania się też rzadziej badawczo rozważany, ale najwyraźniej istotny dla poety wątek tajemnicy człowieka, a mianowicie kwestia jego kondycji jako istoty działającej, spełniającej się poprzez czyn. Dużo już wiemy o Norwidowskiej refleksji nad ludzkim poznaniem i wagą w nim $\mathrm{P}(\mathrm{p})$ rawdy, mniej natomiast o sposobach postrzegania przez pisarza ludzkiego czynu, bez którego prawda nie osiąga przecież w jego przekonaniu swego celu, bo powinna być nieustannie wcielana w życie, poświadczana w działaniu. Spełnienie tego postulatu umożliwiają właśnie cnoty moralne jako formy sprawności duchowej przygotowujące do adekwatnego czynu w świecie, jako sposoby bytowania człowieka $\mathrm{w}$ dyspozycji do czynienia tego, co dobre, co najlepsze.

\section{BIBLIOGRAFIA}

Cnoty $i$ wady [hasło], w: Słownik teologii biblijnej, red. X. Leon-Dufour, przeł. i oprac. bp K. Romaniuk, Poznań 1990, s. 160-162.

Domański J., Chrześcijaństwo a filozofia grecka, „Znak” 1992, nr 1, s. 58-66.

Fert J., Poeta sumienia. Rzecz o twórczości Norwida, Lublin 1993.

Fert J, Wstęp i komentarz, w: C. Norwid, Vade-mecum, oprac. J. Fert, wyd. 2, zmienione, Wrocław 1999. 
Gomulicki J. W., Norwidowe „Idź za mna”, w: C. Norwid, Vade-mecum, tekst opracował oraz wstępem i dodatkiem opatrzył J. W. Gomulicki, wyd. 2, zmienione, Warszawa 1969.

Gryglewicz F., Wegner H., Cnót katalogi, w: Encyklopedia katolicka, red. zbior., t. III, Lublin 1979, s. 527-530.

Heza E., Kryzys arystokratycznego pojęcia areté. Z badań nad historia myśli greckiej, „Etyka" 1972, s. 61-85.

JAEger W., Early Christianity and Greek Paideia, Harvard University Press 1962.

JAeger W., Paideia. Formowanie człowieka greckiego, przeł. M. Plezia, H. Bednarek, Warszawa 2001.

JARosZyŃski P., Kalokagathia, w: Powszechna encyklopedia filozofii, red. nacz. A. Maryniarczyk, t. V, Lublin 2004, s. 444-447.

Katzenellenbogen A., Allegories of the Vitrues and Vices in Medieval Art. From Early Christian Times to the Thirteenth Century, New York 1939.

KLINGER F., Humanität und Humanitas, w: Römische Geisteswelt, Hamburg-München 1961, s. $690-732$.

Kunn H., Humanitas Christiana, w: Interpretationen der Welt. Festschrift Romano Guardini, hrsg. von H. Kuhn, Würzburg 1965, s. 151-171.

Kurek J., Paideia rzymska. Model formowania człowieka w myśli Seneki, Epikteta i Marka Aureliusza, Warszawa 2016.

MacIntyre A., Dziedzictwo cnoty. Studium z teorii moralności, przeł. A. Chmielewski, Warszawa 1996.

Mazurczak M. U., Spes - nadzieja pośród personifikacji cnót. Wokół Andrei Pisana drzwi potudniowych baptysterium we Florencji, „Ethos” 2010, nr 92, s. 183-199.

Melina L. ks., Problematyka cnoty we wspótczesnej teologii moralnej, przeł. P. Mikulska, „Ethos” 2010, nr 92, s. 61-77.

Misztal H., Heroiczność cnót, w: Encyklopedia katolicka, red. zbior., t. IV, Lublin 1993, szp. 798-799.

PAŃPuch Z., Areté, w: Powszechna encyklopedia filozofii, red. nacz. A. Maryniarczyk, t. I, Lublin 2004, s. 318-325.

PańPuch Z., Aretologia, w: Powszechna encyklopedia filozofii, red. nacz. A. Maryniarczyk, t. I, Lublin 2004, s. 325-329.

PAŃPuch Z., Męstwo, w: Powszechna encyklopedia filozofii, red. nacz. A. Maryniarczyk, t. VII, Lublin 2006, s. 140-143.

PAŃPuch Z., W poszukiwaniu szczęścia. Śladami aretologii Platona i Arystotelesa, Lublin 2015.

PatzeK B., Homer i jego czasy, przeł. M. Tycner, Warszawa 2007.

PaWlaK W., Z dziejów pojęcia ,humanitas” (do XVII wieku), w: Humanitas. Projekty antropologii humanistycznej, cz. 1: Paradygmaty - tradycje-profile historyczne, red. A. Nowicka-Jeżowa, Warszawa 2009-2010, s. 168-186.

RiPA C., Ikonologia, przeł. I. Kania, Kraków 2004.

Stabryıa S., Humanitas Christiana w poezji Prudencjusza, w: Świadek Chrystusowych cierpień. Prace dedykowane Księdzu Profesorowi Adamowi Kubisiowi, Kraków 2004, s. 839-853.

StabryŁa S., Z badań nad poezja Prudencjusza, w: Stromata historica in honorem Romani Mariae Zawadzki, Kraków 2006, s. 677-695.

StabryŁa S., Chrześcijański świat poezji Prudencjusza, Kraków 2011. 
Starowieyski M., ks., ,,Psychomachia” Prudencjusza, czyli katecheza o cnotach i grzechach, „Ethos”2010, nr 92, s. 171-182.

StróżEwski W., Doskonate-wypetnienie. O „Fortepianie Szopena” Cypriana Norwida, „Pamiętnik Literacki" 1979, z. 4, s. 43-72.

Stróżewski W., Filozofia człowieka w ,,Vade-mecum” Cypriana Norwida, w: tenże, O wielkości. Szkice z filozofii człowieka, Kraków 2002, s. 7-27.

Stróżewski W., Chopin i Norwid, w: tenże, Wokół piękna. Szkice z estetyki, Kraków 2002, s. 289-307.

Witek S., Wegner H., Cnota, w: Encyklopedia katolicka, red. zbior., t. III, Lublin 1979, szp. 521-527.

WŁodarski M., Motyw ,psychomachii” w literaturze polskiej XV i XVI wieku, „Pamiętnik Literacki" 1983, z. 2, s. 3-22.

ZıoŁowicz A., Norwidowskie miary i oglady heroizmu, „Kultura Słowian. Rocznik Komisji Kultury Słowian PAU” 2018, s. 113-133.

\section{$V A D E-M E C U M$ DROGAMI CNOTY \\ O POETYCKIEJ ARETOLOGII CYPRIANA NORWIDA}

$\mathrm{Str}$ e s z c z e n i e

Artykuł dotyczy obrazowania i koncepcji cnoty w cyklu poetyckim Vade-mecum. Przedmiot analizy stanowią utwory, w których mamy do czynienia z bezpośrednimi nawiązaniami do tej problematyki (Larwa, Fatum, Ironia, Zawody, Centaury, Królestwo, Cnót-oblicze, Bohater, Ideat i reformy, Fortepian Szopena), jednak widzianymi w kontekście całego dzieła pisarza i sytuowanymi na tle starożytnej, greckiej i rzymskiej, oraz chrześcijańskiej refleksji aretologicznej. Poetycka aretologia Norwida pozostaje w ścisłym związku z wymienionymi tradycjami, podlega również inspiracjom literackim (zwłaszcza Homer, Prudencjusz, Dante), a także artystycznym (ikonografia cnoty). Jak dowodzą przeprowadzone analizy, wątek aretologiczny, obejmujący przede wszystkim refleksję nad takimi cnotami, jak męstwo, umiarkowanie, sprawiedliwość i kalokagathia, jest ważnym czynnikiem spójności Vade-mecum (na poziomie kreacji podmiotu dzieła, w epickiej płaszczyźnie cyklu, w obrębie problematyki antropologiczno-etycznej). Jest to zespół zagadnień pozwalających lepiej zrozumieć Norwidowską koncepcję poety-moralisty oraz Norwidowską diagnozę kryzysu człowieczeństwa w XIX wieku.

Słowa kluczowe: Cyprian Norwid; cnota; aretologia; męstwo; umiarkowanie; sprawiedliwość; kalokagathia. 


\title{
PATHS OF VIRTUE IN VADE-MECUM. CYPRIAN NORWID'S POETIC ARETOLOGY
}

\begin{abstract}
This article discusses the concept and imagery of virtue in Norwid's cycle of poems Vademecum, focusing on lyrical pieces that refer directly to this subject ("Larwa" [The Larva], "Fatum" [Fate], "Ironia" [Irony], "Zawody" [Disappointments], "Centaury" [Centaurs], "Królestwo" [Kingdom], "Cnót-oblicze" [Face-of-Virtues], "Bohater" [Hero], "Ideał i reformy" [Ideal and Reforms], "Fortepian Szopena" [Chopin's Piano]). They are nevertheless considered in the light of his entire body of work and on the backdrop of ancient - Greek and Roman - as well as Christian aretology. Norwid's poetic study of virtue remains closely connected with these traditions, but is also inspired by literature (especially Homer, Prudentius and Dante) and art (the iconography of virtue). As analyses demonstrate, an aretology that involves reflection on virtues such as valour, moderation, justice and kalokagathia constitutes an important factor that binds together Vade-mecum at the levels of the development of the lyrical subject, the epic dimension of the cycle, as well as the anthropological and ethical issues it raises. These questions facilitate better understanding of Norwid's concept of a poet-moralist and his diagnosis regarding the crisis of humanity in the nineteenth century.
\end{abstract}

Translated by Grzegorz Czemiel

Key words: Cyprian Norwid; virtue; aretology; valour; moderation; justice; kalokagathia

AgnieszKa ZioŁowicz - prof. dr hab., pracownik Katedry Historii Literatury Oświecenia i Romantyzmu na Wydziale Polonistyki Uniwersytetu Jagiellońskiego. Główne obszary badań: historia literatury romantyzmu i postromantyzmu; dramaturgia wieku XIX; estetyczne i antropologiczne konteksty literatury dziewiętnastowiecznej. Autorka publikacji książkowych (Misteria polskie. Z problemów misteryjności w polskim dramacie romantycznym i modernistycznym; Dramat i romantyczne „Ja”. Studium podmiotowości w dramaturgii polskiej epoki romantyzmu; Poszukiwanie wspólnoty. Estetyka dramatyczności a więź międzyludzka w literaturze epoki romantyzmu (preliminaria), Komedia dworkowa, Eklektyzmy, synkretyzmy, uniwersa. $Z$ estetyki dzieła epoki oświecenia i romantyzmu) oraz artykułów naukowych i edycji tekstów źródłowych. 